\title{
FANATISMO E POLITICA CONTORNOS E RETORNOS DO DISCURSO POLÍTICO-AUTORITÁRIO DE INVOCAÇÃO MESSIÂNICA
}

\author{
FANATICISM AND POLITICS \\ OUTLINES AND RETURNS OF THE \\ POLITICAL-AUTHORITARIAN DISCOURSE \\ OF MESSIANIC INVOCATION
}

\section{FREITAS, Ronaldo Adriano de}

Doutor e mestre em Estudos de Linguagem pela Universidade Federal Fluminense (UFF).

Professor no Instituto Federal de Educação Ciência e Tecnologia Fluminense (IFF-RJ).

E-mail: ronaldo.freitas@iff.edu.br

ORCID ID: https://orcid.org/0000-0001-6081-5146

\section{PERINI, Rudá da Costa}

Mestre em Estudos de Linguagem pela Universidade Federal Fluminense (UFF). Graduado em Letras pela Universidade Federal Fluminense (UFF).

Doutorando em Estudos de Linguagem bolsista CAPES pela Universidade Federal Fluminense (UFF). Professor de Língua Portuguesa na Prefeitura de Itaboraí (SEMED/Itaboraí-RJ).

E-mail: ruda_perini@hotmail.com

ORCID ID: https://orcid.org/0000-0002-9676-5803

\section{RESUMO}

Filiado à Análise de Discurso (Pêcheux-Orlandi) o presente artigo analisa a interrelação entre o discurso religioso e o político, a fim de compreender a organização discursiva que institui práticas autoritárias de Estado. Para isso, ampliamos a discussão efetuada por Klemperer (2009) sobre o funcionamento filológico-discursivo da palavra "fanático" na linguagem nazista, e demonstramos como esse funcionamento retorna na atualidade, analisando os resultados do buscador Google para a palavra fanático, bem como sua implicação no funcionamento do discurso político do governo Bolsonaro.

Palavras-chave: Análise do discurso. Discurso político. Discurso religioso. Fanático. 


\section{ABSTRACT}

Inserted in Discourse Analysis (Pêcheux-Orlandi) this article analyzes the interrelation between religious and political discourse, in order to understand the discursive organization that institutes authoritarian State practices. For this, we extended the discussion carried out by Klemperer (2009) about the philological-discursive functioning of the word "fanatic" in the Nazi language, and we demonstrate how this functioning returns today, analyzing the results of the Google search engine for the word "fanatic", as well how this works in the political discourse of the Bolsonaro government.

Keywords: Discourse analysis. Political discourse. Religious discourse. Fanatic.

\section{INTRODUÇÃO}

Os discursos políticos, muito além de sua função de camuflagem e de autojustificação, constituem também um vestígio, uma rede de indícios para compreender concretamente como se chegou até aqui, e ao mesmo tempo para reconstruir a memória histórica a partir deles (PÊCHEUX, 2014, p. 22)

A questão do/a político/a na linguagem é uma das frentes que caracterizam a Análise do Discurso, tal qual proposta por Michel Pêcheux, na França, como disciplina que busca compreender o funcionamento da ideologia por sua materialização no ordinário da linguagem. Essa questão sempre teve como objeto privilegiado a análise do modo como, na política, em diferentes momentos, se capitulam sentidos que remontam práticas e funcionamentos anteriores, possibilitando o delineamento de uma rede de deslocamentos e repetições que constituem a trama do dizer.

Na epígrafe de nosso texto, Michel Pêcheux (2014) chama a atenção para a especificidade do discurso político, invocando a rede de indícios da memória histórica por ele constituída. Tal colocação se dá no prefaciamento do trabalho de Courtine (2014), obra em que o conceito de condições de produção é intensamente desenvolvido para compreensão das relações históricas entre o discurso religioso e o discurso político.

É por essa entrada que propomos, no presente artigo, o delineamento do que denominamos o discurso político autoritário de invocação 
messiânica ${ }^{1}$, na busca por historicizar o modo pelo qual o proselitismo na política deve ser associado a um discurso de interpretação unívoca de dominação e anulação de quaisquer forças que venham a ele se opor. Procuramos, assim, compreender o funcionamento do discurso religioso como constitutivo das condições de produção do discurso político do presidente brasileiro Jair Messias Bolsonaro em sua relação com o religioso.

O gesto analítico que aqui imprimimos é constituído por três movimentos: Inicialmente, tomamos a análise efetuada por Klemperer (2009) sobre o funcionamento filológico-discursivo da linguagem nazista, em especial da palavra "fanático", tomada como índice do funcionamento que aqui procuramos analisar, produzindo um batimento entre tais análises e posicionamentos de Adolf Hitler em "Mein kampf", livro que no Brasil foi traduzido como "Minha luta". No segundo movimento, procuramos rastros desse funcionamento em discursos de organização lexical que caracterizam nossa sociedade, entendendo como exemplos desses discursos os buscadores da internet e os dicionários online veiculados por estes buscadores. Por último, mostramos como esse funcionamento retorna na atualidade, na emergência de um discurso político que advoga elementos da religiosidade como estruturante de suas práticas.

\section{O TERMO "FANÁTICO" E A RELAÇÃO ENTRE AUTORITARISMO E RELIGIOSIDADE}

A relação entre o político e o religioso é tema de inúmeros trabalhos que buscam compreender o funcionamento do tecido social e as relações que nele se constituem. A história nos ensina que "As primeiras formas de poder concentrado e de institucionalização política foram construídas por sacerdotes-reis" (CLAVAL, 2011, n.p.); de modo que, para esse autor, a religião opera como "fonte da autoridade política" (ibidem). Entre os que teorizaram essa relação, Maquiavel (2011) exorta ao príncipe que "deves parecer piedoso, fiel, humano, íntegro, religioso e sê-lo, mas com a condição de estares com ânimo disposto a, quando necessário, não o seres, de modo que possas e saibas tornar-te o contrário" (MAQUIAVEL, 2011, p. 87).

1. Optamos por "messiânica" em vez de religiosa aqui em referência ao segundo nome do presidente, do qual ele mesmo já se valeu para produzir dizeres como: "E daí? Lamento. Quer que eu faça o quê? Sou Messias, mas não faço milagres". Fala proferida em abril de 2020 durante coletiva de imprensa resposta a questionamento sobre o número de mortes causadas pela pandemia de COVID-19. Disponível em: https://noticias.uol.com.br/ videos/2020/04/28/sou-messias-mas-nao-faco-milagres-diz-bolsonaro-sobre-recorde-de-mortes.htm. Acesso em: 29 set. 2020 
Ames (2002) afirma que para esse autor renascentista "a religião ensina a reconhecer e a respeitar as regras políticas a partir do mandamento religioso" (AMES, 2002, n.p.). Destacando ainda a possibilidade de que essa ação diga respeito tanto ao "aspecto coercivo exterior da disciplina militar ou da autoridade política quanto o caráter persuasivo interior da educação moral e cívica para a produção do consenso coletivo" (ibidem). Na mesma direção, séculos depois, Althusser (1985) põe em primeiro lugar na lista de aparelhos Ideológicos de Estado (AIE) Os AIE religiosos; mostrando o funcionamento do discurso religioso na conformação do Estado, uma vez que "os AIE 'funcionam' predominantemente através da ideologia, o que unifica a sua diversidade" (ALTHUSSER, 1985, p. 70-71).

O funcionamento social do discurso religioso é, portanto, parte do cimento ideológico, de modo que, nas palavras do propositor da teoria dos Aparelhos Ideológicos de Estado, "a ideologia na qual funcionam, está de fato sempre unificada, apesar de sua diversidade e contradições, sob a ideologia dominante, que é a ideologia da 'classe dominante'" (ibidem) . O discurso religioso participa, portanto, de um processo de contigenciamento das demandas das classes sociais dominadas aos interesses dominates, estabilizando (pela dominação) a organização social.

No entanto, não é desse funcionamento sistematizante que tratamos aqui ao propor a interrelação entre o discurso religioso e o político, mas da apropriação do funcionamento do discurso religioso pelo discurso político. A designação "discurso político autoritário", que ora propomos, diz respeito aos modos de organização discursiva que instituem a necessidade/legitimidade da aniquilação/destruição (mesmo física) de oponentes. Propomos tal designação a partir de Orlandi (2011), que denomina discurso autoritário "aquele em que a reversibilidade tende a zero, estando o objeto do discurso oculto pelo dizer, havendo um agente exclusivo do discurso e a polissemia contida. O exagero é a ordem no sentido militar" (ORLANDI, 2011, p. 154).

Se para a autora, o exemplo de exagero desse tipo de discurso é a "ordem no sentido militar", acrescentamos que no discurso político autoritário é a própria possibilidade de que um discurso a ele se oponha que é interditada, submetendo a própria existência civil a tal "ordem"; pela produção discursiva de jogo de antecipação, qualquer outra posição é indigna, abominável e ameaçadora, devendo ser calada a qualquer preço. É a criação de "valores absolutos" que sustenta a possiblidade 
de destruição, não só da ideia de seu opositor, mas do próprio opositor tomado como inimigo.

O funcionamento de um discurso único, inquestionável, dado como um valor em si carrega uma forte relação com o discurso religioso, cuja sustentação é provida pela inquestionável ordem do sobrenatural. Para pensarmos essa relação entre o discurso político autoritário e o discurso religioso, tomamos por base o discurso produzido ao longo do governo nazista de Adolf Hitler, que embora apoiasse seu discurso de eugenia em duvidosas bases pseudocientíficas, não deixa de adotar o modo de funcionamento do discurso religioso como forma de anulação do discurso opositor, conforme mostramos a seguir.

A relação entre linguagem e autoritarismo é o objeto de análise de Victor Klemperer em LTI: a linguagem do terceiro reich. Nessa obra, Klemperer ilumina aspectos da linguagem alemã, em uso no período da segunda guerra mundial, que desvelam a tese primordial do livro: a consolidação do nazismo se deu na medida em que dominou a linguagem; isto é, o poder exercido pelo regime nazista, através de mecanismos imaginários e inconscientes, impõe controle sobre a linguagem, logo sobre o pensamento.

O nazismo se embrenhou na carne e no sangue das massas por meio de palavras, expressões e frases impostas pela repetição, milhares de vezes, e aceitas inconsciente e mecanicamente. [...] O que acontece se a língua culta tiver sido constituída ou for portadora de elementos venenosos? Palavras podem ser como minúsculas doses de arsênico: são engolidas de maneira despercebida e parecem ser inofensivas; passado um tempo, o efeito do veneno se faz notar (KLEMPERER, 2009, p. 55-57).

Com uma mescla aterradora de autobiografia e análise linguística, Klemperer - filólogo, professor universitário, marido, alemão, judeu - nos coloca advertidamente diante de uma experiência dura e cruel vivenciada por ele e sua esposa, Eva Klemperer, ao sobreviverem ao regime nazista, então autointitulado Terceiro Reich.

O autor assiste perplexo o encadeamento de fatos históricos; da ascensão do partido nazista com apoio de grande parte do povo alemão ao fim da guerra; a derrocada dos exércitos alemães e o suicídio de seu führer, Adolf Hitler. Klemperer presencia a consolidação do poder autoritário guiado por forte ideologia antissemita que implica, 
ascendentemente, na medida em que se fixa pela via da linguagem, de exclusão social e confisco de bens a perseguição, exílio ou extermínio dos judeus nos campos de concentração. O olhar de alguém que vivencia tais acontecimentos, nos permite enxergar vários níveis do processo, porém as lentes filológicas de Klemperer clareiam o fio condutor da obra, o estudo da linguagem: palavras surgem, palavras desaparecem, intensifica-se o uso de certos prefixos, determinados estrangeirismos se tornam frequentes, palavras são ressignificadas, etc.

Um dos processos de ressignificação trabalhados por Klemperer aponta o caminho da construção do dispositivo analítico que delineamos para compreensão do entrelaçamento entre o discurso religioso e o discurso político autoritário caracterizador do nazismo: no capítulo 9, intitulado Fanático, algo da ordem da familiaridade nos captura na leitura e, entre tantas coisas estranhamente familiares, nos faz parar. Explicamos. Nesse capítulo, vemos como a LTI traz as palavras "fanático" e "fanatismo", não originárias da língua alemã, para atender a seu projeto perverso de controle da linguagem, das mentes e dos corpos.

Como demonstra Klemperer, a significação possível até 1932, um ano antes da tomada do poder pelo partido nazista, era com "forte carga negativa, com conotação de ameaça e repulsa [...] uma qualidade malvista, algo a meio caminho entre crime e doença" (KLEMPERER, 2009, p. 114). A LTI, contudo, provoca ruptura nessa filiação de sentidos, passando "fanático" a significar positivamente, isto é, "tratava-se de supervalorizar conceitos como valentia, dedicação, abnegação, tenacidade ou, mais precisamente, fazer um enunciado global que associava de maneira gloriosa todas essas virtudes" (ibidem, p. 115).

A percepção dessa utilização pode ser rastreada nas palavras do próprio líder nazista, Adolf Hitler, que, ao compor o manual para da operação genocida, Mein Kampf, obra considerada a bíblia nazista, escreve:

O futuro do movimento depende do fanatismo, mesmo da intolerância, com a qual seus adeptos o defenderem como a única causa justa e defenderem-na em oposição a quaisquer outros esquemas de caráter semelhante.

A grandeza de toda organização ativa que corporifique uma ideia está no fanatismo religioso e na intolerância com que agride todas as outras, convencidos os seus adeptos de que só eles estão com a razão. 
A grandeza do Cristianismo não está em qualquer tentativa para reconciliar-se com as opiniões semelhantes da filosofia dos antigos, mas na inexorável e fanática proclamação e defesa das suas próprias doutrinas (HITLER, 1934, p. 152).

É o próprio Hitler que associa o movimento nazista à formulação de um fanatismo como forma de desenvolvimento de um sentido único, incapaz de ouvir e capaz de atacar quaisquer outros sentidos que possam se opor a verdade por ele apregoada, tomada nas palavras do autor como "única causa justa". O mesmo autor, na sequência, certifica que o modelo se baseia no funcionamento do discurso religioso, garantidor de posse da razão centralizada capaz de corporificar uma ideia; é ainda o mesmo autor que indicará esse funcionamento no cristianismo, reconhecendo a grandeza do Cristianismo enquanto movimento que lhe inspira.

Retornando a Klemperer, "fanático", na LTI, passa a ser empregado no lugar de "apaixonado". Com a repetição e as frequentes tentativas de naturalizar esse sentido positivo, que se intensificam ao passo que a derrota na guerra se torna iminente e o fanatismo se torna ainda mais necessário para permanência do Terceiro Reich, a palavra se embota e escapa de vez à tentativa de se fixar o sentido positivo.

Essa mudança de sentidos não se dá sem a contradição que é própria do funcionamento da língua, isto é, a palavra pode significar " $\mathrm{x}$ " e também " $y$ ". Klemperer exemplifica, em outros termos, esse processo:

Antes do Terceiro Reich ninguém poderia ter pensado em valorizar positivamente o termo "fanático". E a conotação negativa está associada de forma tão indelével à palavra que a própria $\mathrm{LTI}$, vez por outra, a usa com sentido negativo. Em Mein Kampf, Hitler fala com desdém dos Objektivitätsfanatiker [fanáticos da objetividade]. No período áureo do Terceiro Reich surgiu uma monografia enaltecedora, escrita por Erich Gritzbach, chamada Hermann Goring, obra e personalidade, totalmente alinhada aos clichês da linguagem nazista, na qual constava que a mais indigna das heresias, o comunismo, provou ser capaz de educar o povo para que ele se tornasse mais fanático. Esse caso é um deslize quase cômico, uma impossível recaída no emprego da linguagem de outrora. Aconteceu, em casos isolados, até com o próprio mestre da LTI. Em dezembro de 1944, certamente tendo como modelo o pronunciamento de Hitler, Goebbels ainda fala 
no "fanatismo confuso de alguns alemães incorrigíveis" (KLEMPERER, 2009, p. 114-115).

Como sinaliza Klemperer, aí se dá o "revés da palavra" (ibidem, p. 116).

Para pensar este movimento, recorremos às noções de paráfrase e polissemia. Orlandi entende que a paráfrase está para a produtividade, o "constante retorno a um mesmo espaço dizível" (2011, p. 137). Já a polissemia está para a criatividade, "desloca o 'mesmo' e aponta para a ruptura" (ibidem). Esses dois processos convivem em tensão no funcionamento da língua. Como vimos, no nazismo, a LTI foi capaz produzir a ressignificação da palavra "fanático", porém não sem contradição; o que faz surgir um sentido outro que não o é sem o mesmo. Aí se confronta um processo de ruptura com a força de um processo parafrástico que se recusa a desaparecer.

Klemperer fecha o capítulo Fanático com as seguintes palavras:

[...] enquanto por toda a parte restos da LTI são assimilados pela linguagem atual, a palavra fanatisch desapareceu. $\mathrm{O}$ que nos permite concluir que, na consciência popular, a verdade se manteve viva: um estado de espírito confuso, próximo da doença e do crime, havia sido considerado como virtude suprema durante doze anos (ibidem).

O desaparecimento da palavra "fanático" após a queda do regime nazista é registrado por Klemperer como um sintoma do esvaziamento do poder de circulação do discurso nazista. Se no apogeu dessa circulação "fanatismo" circula como qualidade almejada, a queda do império marca a volta de seu sentido depreciativo, o retorno e a prevalência de uma memória popular que associa a palavra à doença e ao crime, termos que, embora excludentes, trazem o sentido comum de algo a ser combatido.

A análise proposta por Klemperer e os excertos de Hitler dão pistas importantes para a compreensão da articulação entre o discurso político autoritário e o religioso. Klemperer aponta o termo "fanático" como índice do funcionamento de um discurso que subverte a vontade de um grupo a outro, pela identificação deste a valores inquestionáveis, imutáveis, sobrenaturais. O reconhecimento desses valores como "única causa justa" não se justifica por nenhuma razão, mas por um idealismo fundante, fundamentalista. Recorremos novamente ao discurso do próprio Hitler, que relaciona a habilidade de liderança dos grandes estadistas e generais ao dom divino: 
Assim como um célebre artista não pode ser substituído e nenhum outro acerta concluir um quadro já quase pronto, o mesmo acontece com os grandes poetas e pensadores, os grandes estadistas e os grandes generais. A sua atividade não é formada mecanicamente, mas é um dom da graça de Deus (HITLER, 1934, p. 153).

A relação entre o atributo divino do grande estadista, proclamado por Hitler, e o fanatismo de seus seguidores, demonstra o modo de articulação do discurso nazista, que ora tomamos como característico do discurso político autoritário de invocação messiânica. O grande estadista deve ser interpretado como possuidor dessa graça, que torna seus desígnios inquestionáveis e seus opositores inimigos. Os sentidos em jogo nesse tipo de discurso não é a lógica, ou a ética, mas a confiança inquestionável exercida pelo líder. É essa confiança, da ordem do sobrenatural, que produz o fanatismo.

Retomando Orlandi, encontramos o que ela denomina como "modos de representação e obscuridade" (ORLANDI, 2011 p. 244), isto é, o "mecanismo de incorporação de vozes [...] uma voz que se fala na outra da qual é representante" (ibidem). A autora exemplifica: "quando digo que a voz de Deus se fala no padre, é 'como se' Deus falasse: a voz do padre é a voz de Deus. Essa é a forma da representação, ou seja, da relação simbólica" (ibidem, aspas e itálico da autora). Antes disso, na mesma página, a Orlandi dispõe:

Podemos fazer um paralelo entre o discurso religioso e outros tipos de discurso:

a) No discurso religioso: a voz de Deus se fala no padre;

b) No discurso político: a voz do povo se fala no político;

[...] Essa é, para nós, a forma da mistificação: em termos de discurso, é a subsunção de uma voz pela outra (estar no lugar de), sem que se mostre o mecanismo pelo qual essa voz se representa na outra. O apagamento da forma pela qual o representante se apropria da voz é que caracteriza essa mistificação. (ibidem, itálico da autora) 
Esse paralelo estabelecido pela autora é a chave para a compreensão do que aqui tratamos como o discurso político autoritário de invocação messiânica: seu funcionamento deriva da apropriação invertida das vozes que caracterizam o discurso religioso e o político. Enquanto no modelo produzido por Orlandi, a voz de Deus se manifesta no discurso religioso; e a voz do povo, no discurso político; no discurso político autoritário de invocação messiânica é a voz de Deus que se manifesta no político - inversão fundamental para seu funcionamento.

Nessa inversão, interdita-se a relação entre a voz do povo e a voz de Deus afirmada no dito popular pela "assimetria fundamental que caracteriza a relação falante/ouvinte no discurso religioso, [...] há uma separação (diferença?) entre a significação divina e a linguagem humana" (ibidem, p. 245). Nesse desnivelamento, se a voz do povo, baseada na linguagem humana, é capaz de sustentar dissonâncias, equívocos e contrariedade; a voz de Deus é unívoca, singular e superior. Não há nos desígnios divinos espaço para a interpretação, pois a própria interpretação, uma vez regulada pelo funcionamento do discurso religioso, se constitui manifestação da vontade divina e injunção à adesão.

O fanatismo, conclamado pelo regime nazista, funciona assim como o reconhecimento dessa propriedade divina de representação na fala do líder político, que reclama para si, verbal ou ritualisticamente, esse lugar de representação e as propriedades que dela derivam, capazes de estabelecer à toda e qualquer contrariedade o lugar de inimigo a ser destruído pela desqualificação da própria possibilidade de sustentação desse outro como heresia, imoralidade e abjeção.

\section{A CIRCULAÇÃO DE "FANÁTICO" NA CONTEMPORANEIDADE}

A inversão que explicitamos acima nos conduz de volta ao processo de produção de sentidos de "fanático". A fim de compreender o funcionamento de sublimação do sentido produzido pelo regime nazista e registrado por Klemperer, registramos a atualização dos sentidos do termo nas atuais condições de produção no intuito de rastrear possíveis resquícios desses sentidos, aqui tomados como índices dessa representação do discurso religioso nas práticas políticas; ensejando que, como desenvolvemos, a invocação dessa representação constitui marca categórica do autoritarismo enquanto prática política, dada a relação assimétrica que a sustenta. 
Para tal registro, recorremos a Freitas (2020), que, ao analisar o funcionamento dos buscadores de internet como ferramentas de gestão lexical contemporâneas, demonstra que esses dispositivos - em especial o Google, por seu poder de circulação - trabalham "como porta de entrada para a consulta lexical na internet, cumprindo por vezes a atividade meio e a atividade fim; caminho e chegada dessas consultas" (FREITAS, 2020, p. 98). Considerando, assim, com o autor, que essas ferramentas instrumentalizam a língua, produzindo nela a injunção ao dizer e a legitimação das práticas discursivas com a materialização de suas contradições, buscamos indícios do funcionamento de "fanático" na atualidade. Para tanto, procedemos à consulta do termo no buscador Google, obtendo o seguinte resultado: ${ }^{2}$

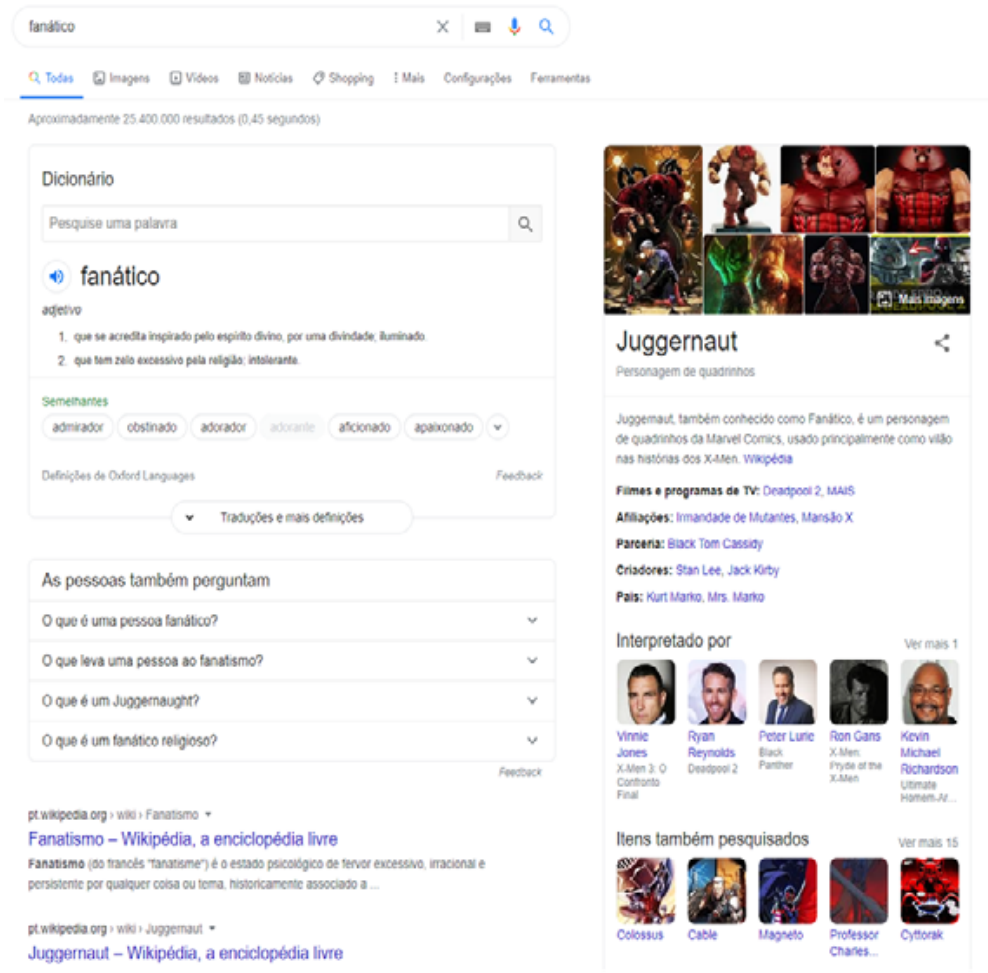

Figura 1:

Fonte: Captura de tela. Pesquisa pela palavra "fanático" no buscador Google. Acesso em 20 set. 2020

2. Até a data de 20 de setembro de 2020, o primeiro resultado apresentado pelo buscador era o de nomeação do personagem em quadrinhos "Fanático" (Juggernaut), seguido pela referência à Wikipédia, e, só depois, dicionários online. A partir dessa data o Dicionário Google passou a ocupar o lugar de destaque nas pesquisas. 
Os primeiros itens retornados pela busca podem ser assim descritos: em primeiro plano, o acionamento do Dicionário Google, que apresenta o tratamento lexicográfico produzido para "fanático" nos seguintes termos:

Fanático
Adjetivo
1. que se acredita inspirado pelo espírito divino, por uma
divindade; iluminado.
2. que tem zelo excessivo pela religião; intolerante.
Semelhantes
Admirador; obstinado; adorador; adorante; aficionado;
apaixonado

Ocupando também o plano principal, a coluna lateral da página de respostas faz referência a "Fanático" como nome de um personagem de histórias em quadrinhos:

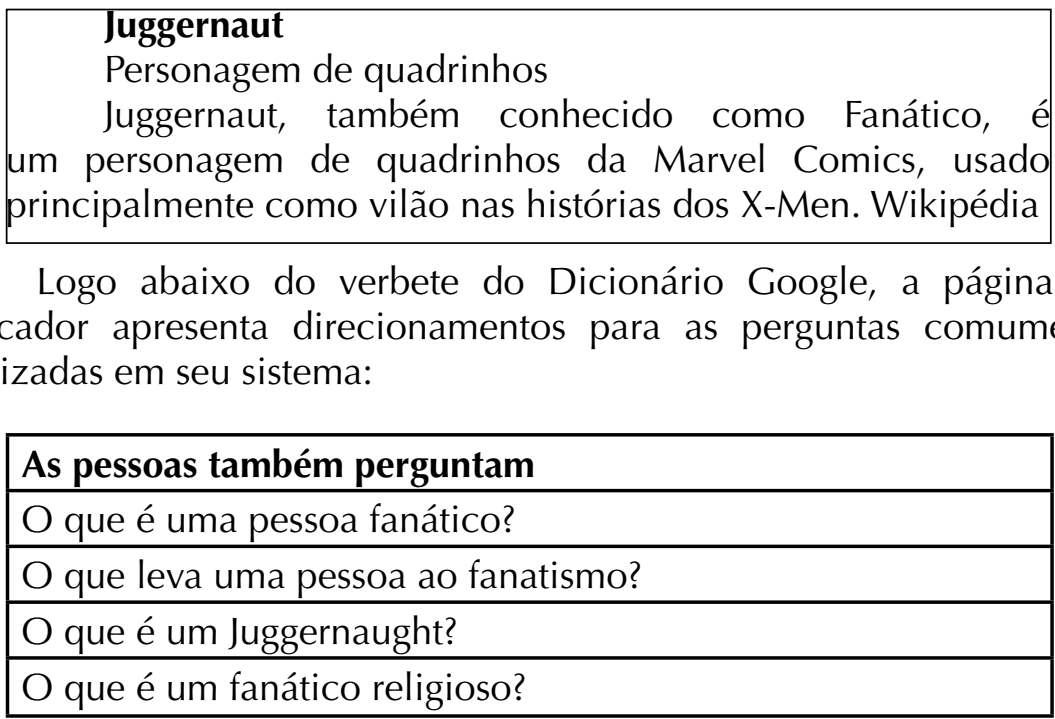

Ainda mais abaixo, a página apresenta outras ligações para a Wikipédia e para outros dicionários online: 


\section{4) fanático}

adjetivo

1. que se acredita inspirado pelo espirito divino, por uma divindade; iluminado

2. que tem zelo excessivo pela religiảo; intolerante.

3. que se mostra excessivamente entusiástico, exaltado, de uma devoçăo quase sempre cega: apreciador apaixonado. f. por futebol, por música

4. substantivo masculino individuo fanático

\section{Origem}

○ ETIM lat. fanaticus, a, um 'que pertence ao templo, que é inspirado pelos deuses, entusiasmado, apaixonado', pej. 'louco, delirante, furioso, fanático'

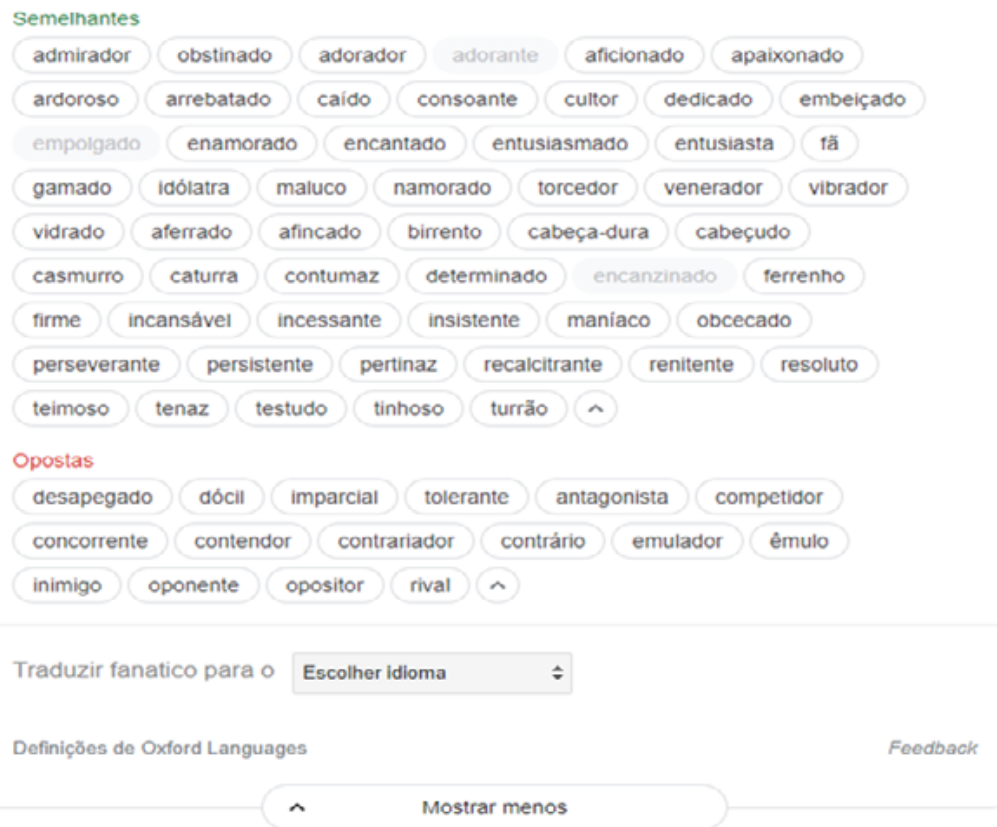

Figura 2:

Fonte: Captura de tela. Outras ligações apresentadas pela pesquisa por "fanático" no buscador Google. Acesso em 20 set. 2020.

A leitura dos itens descritos acima permite algumas análises que demonstram o funcionamento contraditório do termo "fanático" em circulação no atual momento. Essa contradição é marcada na língua por relações de sentidos que comparecem nos resultados mostrados. Tomemos inicialmente a coluna lateral que designa um personagem de história em quadrinhos: 


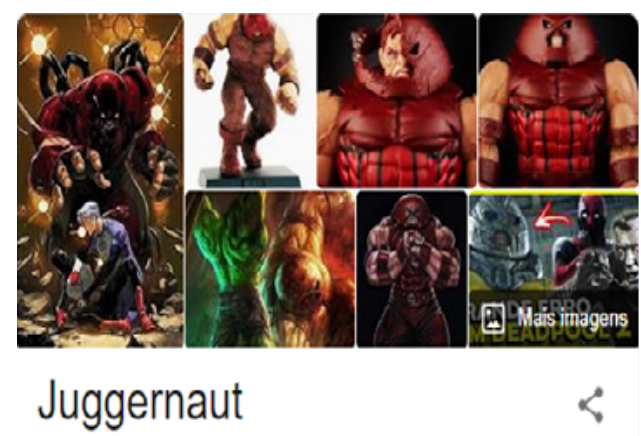

Personagem de quadrinhos

Juggernaut, também conhecido como Fanático, é um personagem

de quadrinhos da Marvel Comics, usado principalmente como vilão

nas histórias dos X-Men. Wikipédia

Figura 3:

Fonte: Captura de tela. Coluna lateral da pesquisa por "fanático" no buscador Google. Acesso em 20 set. 2020.

O funcionamento da contradição se marca, por um lado, no lugar de "vilão" atribuído ao personagem; produzindo-lhe o lugar do crime e da maldade; mas antecipada, pelo advérbio "principalmente", a possibilidade de em determinados momentos, não ocupar tal lugar de vilania. Fanático é, não necessariamente, vilão; podendo em alguma situação, ser também o herói.

Por sua vez, os demais registros da palavra "fanático" estão, num primeiro momento, diretamente ligados à ideia de religiosidade, sustentando a relação que apontamos em nosso trabalho entre o apelo à religiosidade e o fanatismo requerido pelo discurso autoritário do nazismo. Na seção de perguntas comuns apresentada pelo sistema de buscas, além da relação com o personagem da história em quadrinhos, destacamos a presença da construção "fanático religioso", além da oposição entre as perguntas 1 e 2: "O que é uma pessoa fanático?"; "O que leva uma pessoa ao fanatismo?". Se na primeira pergunta o verbo "ser" aponta para "fanático" como uma característica da "pessoa", na segunda destaca-se um processo que "leva uma pessoa" a essa condição. Novamente não há nexo entre fanatismo e alguma falha constitutiva.

Por último, o verbete de dicionário oferece diversos elementos a nossa análise. Na versão resumida apresentada no carregamento da página, as duas definições apresentadas ligam diretamente "fanático" à ideia de religiosidade. A primeira delas apresenta, justamente, a relação necessária entre o seguidor e o líder político que advoga para 
si a iluminação divina como atributo de governabilidade "que se acredita inspirado pelo espírito divino, por uma divindade; iluminado", definição que coloca o fanatismo como condição para o funcionamento do discurso político autoritário de invocação messiânica. A segunda definição "que tem zelo excessivo pela religião; intolerante" atrela o fanatismo ao excesso e à intolerância; marcas de todo discurso que se pretende aceito como "verdade absoluta".

No entanto, a própria versão resumida do verbete apresenta como palavras semelhantes: "admirador" e "apaixonado", sentidos que Klemperer (2009) destacada em sua análise do discurso nazista:

Essa frequência da palavra no domínio da política a projetou para outras áreas, graças aos escritores ou à conversa diária. Onde antes se dizia ou escrevia leidenschaftlich [apaixonado], passou-se a dizer "fanático". Para que isso acontecesse foi necessário submeter o conceito a um certo enfraquecimento, uma espécie de banalização, uma perda de dignidade (ibidem, p. 114).

Essa possibilidade de sentidos de conotação positiva para "fanático" fica mais assertiva quando o clique sobre o comando <Traduções e mais definições $>$ (cf. figura 1), expõe o sentido depreciativo da terceira entrada do dicionário, "que se mostra excessivamente entusiástico, exaltado, de uma devoção quase sempre cega; apreciador apaixonado.", é modalizado - há uma abertura entre "devoção cega" e "devoção quase sempre cega" que comparece na definição. Essa abertura é ratificada pelos exemplos dados nessa definição, uma vez que "f. por futebol, por música" possuem em nossa sociedade uma dimensão bastante positiva; não sendo estranha a figura de um "torcedor fanático pelo seu time". Há, portanto, nessas construções, espaço para a relativização do termo fanático, uma vez que a própria ideia de excesso trazida pelo dicionário não evidencia um demérito, pois traz uma memória de dedicação e zelo propagadas pelo discurso religioso.

A correlação entre a possibilidade de existência de "um bom fanático' (O fanático do bem) e o "que se acredita inspirado pelo espírito divino" trazido na primeira definição mostram que, apesar de certa interdição que pesa sobre "fanático", há no trabalho de sua definição espaço para a interpretação de aspectos positivos; o que denuncia a possibilidade, marcada na língua, de desenvolvimento desse sentimento/ condição no processo de produção de subjetividades de nosso atual momento. 


\section{O PROSELITISMO POLÍTICO DO GOVERNO BOLSONARO}

Considerada a relação entre o fanatismo, o funcionamento do discurso político autoritário, e a possibilidade de concepção de aspectos do fanatismo tomados como positivos em nossa sociedade (por consequência, da possibilidade de ancoramento de subjetividades nesses sentidos) passamos a descrever brevemente algumas sequências discursivas produzidas ao longo do governo de Jair Bolsonaro que estabelecem conexões entre o funcionamento que descrevemos e a eficácia do discurso desse governo junto a seus apoiadores. Listamos assim 3 sequências discursivas que representam essa relação:

SD1: A adoção de um slogan de campanha, repetido ao longo de seu governo, em que há invocação do discurso religioso: "Brasil acima de tudo. Deus acima de todos".

SD2: A declaração dada pelo presidente em 10/07/2019, em culto evangélico na Câmara dos Deputados, de que indicaria para o Supremo Tribunal Federal um ministro "terrivelmente evangélico": "Muitos tentam nos deixar de lado dizendo que o estado é laico. O estado é laico, mas nós somos cristãos. Ou para plagiar a minha querida Damares [Alves, ministra]: Nós somos terrivelmente cristãos. E esse espírito deve estar presente em todos os poderes. Por isso, o meu compromisso: poderei indicar dois ministros para o Supremo Tribunal Federal [STF]. Um deles será terrivelmente evangélico" ${ }^{\prime \prime}$.

SD3: A condução de uma celebração ecumênica, em 12/04/2020, em que a partir do Palácio do Planalto, e com transmissão pela TV Brasil (Estatal), o presidente se reuniu com cerca de 20 líderes religiosos para celebrar a páscoa, e que segundo o site oficial do governo brasileiro teve por objetivo "levar mensagens de fé ao povo brasileiro"4.

As três sequências acima demonstram o funcionamento do discurso político do atual governo: marcado como um compromisso eleitoral, a presença da religiosidade se materializa de dentro pra fora e de fora para dentro. Ao declarar critérios religiosos em um ato de governo da

3. Disponível em: https://g1.globo.com/polit

ica/noticia/2019/07/10/bolsonaro-diz-que-vai-indicar-ministro-terrivelmente-evangelico-para-o-stf.ghtml. Acesso em: 30 jul. 2020.

4. Disponível em: https://www.gov.br/planalto/pt-br/acompanhe-o-planalto/noticias/2020/4/presidente-bolsonarose-reune-com-lideres-religiosos-em-celebracao-de-pascoa. Acesso em: 30 jul. 2020 
importância de uma indicação para o Supremo Tribunal Federal, o presidente se inscreve como representante de um segmento religioso na estrutura dos poderes federativos, por outro lado, ao unir autoridades religiosas sobre a sua tutela, ele assume o lugar de líder religioso, e como tal, assume o lugar de escolhido por Deus para o comando do país.

A estrutura de um governo autoritário está intimamente ligada à adesão das massas a essa autoridade. O autoritarismo não funciona sem a legitimação de um segmento que o apoie e suporte. Em outras palavras, o autoritarismo não é para todos; é o tratamento dado ao discurso de oposição que caracterizará seu funcionamento.

Chamamos a atenção para o funcionamento histórico do processo de laicização do governo brasileiro. As tomadas de práticas religiosas remetem ao império, quando a relação religião/estado era regida pelo patronato, que concedia ao imperador autoridade sobre as decisões eclesiásticas. "Com o padroado, os religiosos eram uma espécie de funcionários do Estado, devendo obediência ao chefe de Estado" (HEINSFELD, 2021, p 197). O que aponta para a base teocrática da formação do Estado brasileiro.

Ao longo de toda república, o discurso político por diversas vezes flertou com o religioso, mas essa relação nunca foi assumida e oficializada. A menção ao funcionamento do discurso religioso foi sempre regrada por uma ética laicizante que agora é quebrada em nome de um discurso de representatividade do cristianismo enquanto coletivo denominacional religioso culminado na eleição de um presidente "escolhido por Deus" e autorizado a agir em seu nome.

Esse discurso produz o efeito de legitimação dos atos de governo e colocação da figura de Bolsonaro como o legítimo representante de Deus. Essa representação se materializa no discurso de seus seguidores, que projetam na imagem de Bolsonaro a do próprio Cristo, perseguido e acusado apesar de sua dignidade. É o que vemos na imagem abaixo, divulgada nas redes sociais de uma deputada da base aliada do governo Bolsonaro: 


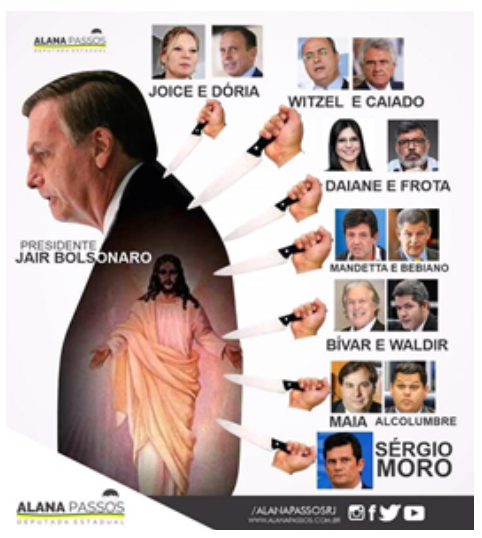

Figura 4:

Fonte: Imagem que circulou nas redes sociais ${ }^{5}$.

Trata-se, como falamos, de um discurso de interpretação unívoca de dominação e anulação de quaisquer forças que venham a ele se opor: os que se opõe a Bolsonaro estão esfaqueando o próprio Cristo por ele representado. Comparece aí de maneira bastante significativa o entrecruzamento da imagem de Jair Messias Bolsonaro com a imagem do messias Jesus. Se Jair Messias é o próprio Jesus messias encarnado, todos os que se opõe são traidores, Judas.

De volta à palavra "fanático", encontramos entre os resultados apresentados pelo Google como "semelhantes" (ver figura 2) um termo corrente que compartilha a mesma raiz etimológica. Entre as muitas palavras ali registradas, "fã" é constituída pela redução de fanático:

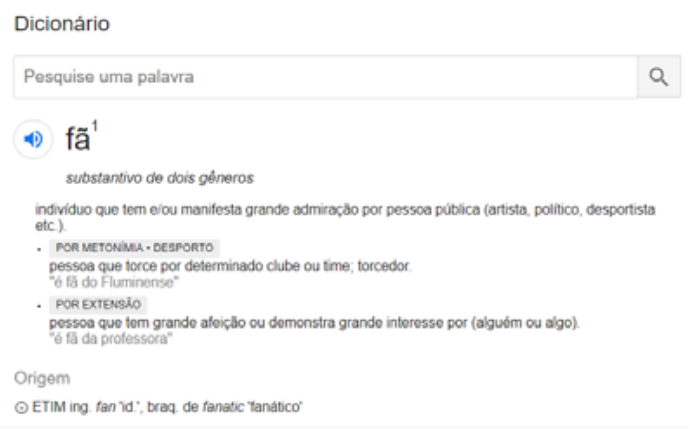

Figura 5:

Fonte: Captura de tela. Resultado para pesquisa da palavra "fã" no buscador Google. Acesso em 20 set. 2020.

5. Disponível em: https://www.facebook.com/steffesomfreitasdireita.avozdopovo/posts/695438327880240/. Acesso em: 30 jul. 2020. 
Trata-se de processo de redução morfológica e semântica: reduzse o tamanho da palavra e sua carga semântica discursiva; que já não carrega o sentido pejorativo interditivo de fanático. Se, como mostramos, a palavra "fanático" já estaria autorizada a circular positivamente em determinadas situações (os esportes, por exemplo), a palavra "fã" tem livre circulação por representar a grande afeição dedicada ao objeto de devoção.

É nesse item lexical que mais uma vez demonstramos os efeitos do discurso político autoritário de invocação messiânica no governo de Bolsonaro. Se seus detratores são inimigos, os que o apoiam são seguidores, fãs.
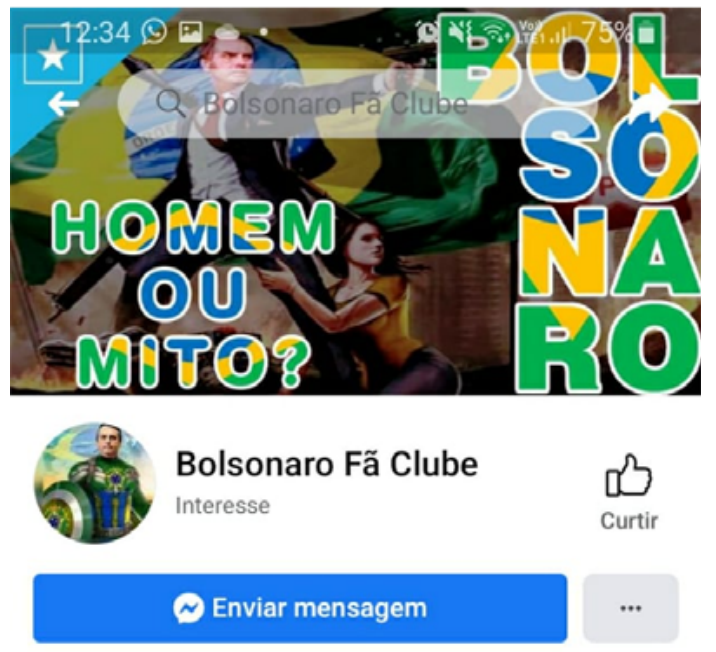

20.714 pessoas curtiram isso

Página inicial Loja Avaliações Fotos Videos

Figura 6:

Fonte: Captura de tela. Página "Bolsonaro Fã Clube" na rede social Facebook

A relação entre um presidente que evoca a religiosidade como marca de seu governo e a adesão a esse discurso sob a designação de fã demonstra como tal discurso "cola" na sociedade. A existência do "fã" na cadeia parafrástica de "partidário", "militante", "seguidor", "fã" demonstra o deslocamento entre a adesão a ideias para a adesão à

6. Disponível em: https://www.facebook.com/Bolsonaro-F\%C3\%A3-Clube-103659924308414. Acesso em: 30 jul. 2020. 
personalidade do líder. A relação rompe com o campo da identificação ideológica para o campo da "grande afeição". Fã, nesse caso, recupera o lugar histórico-discursivo de fanático, lugar da adesão irredutível e da tomada dos que a ele se opõe como inimigos a serem combatidos.

\section{CONSIDERAÇÕES FINAIS}

No presente artigo, propusemos um caminho de investigação do discurso político que se principia pelas coordenadas deixadas por Klemperer (2009) ao examinar a língua nazista. Para tanto, traçamos um percurso investigativo que buscou abordar o enlace entre discurso político e discurso religioso a partir de um olhar para a historicidade e funcionamento da língua na atualidade em batimento com fragmentos de discursos de Hitler sobre os quais, pode-se concluir:

As coisas ditas, os modos de dizer e mesmo os silêncios de Hitler concorrem para estabelecer e reforçar o que seria sua estreita ligação com Deus: 'O Führer reiterou o seu relacionamento estreito com a divindade, sua condição especial de eleito e filho de Deus, sua missão religiosa' (PIOVEZANI; GENTILE, 2020, p. 17).

Nessa visada, analisamos como o fanatismo, nas condições de produção hodiernas, pode ser significado como uma qualidade. Para tal, retornamos às considerações feitas por Klemperer (2009) a respeito da palavra "fanático" no período de dominação nazista. Como demostra o filólogo, a necessidade do regime nazista em arrebanhar seguidores fiéis para que seu projeto político imperialista atroz funcionasse implicou, entre outras coisas, numa mudança na língua.

Fanatismo, que antes poderia ser considerado algo repulsivo, na linguagem nazista passou a significar uma valorosa qualidade. Como expomos, esse traço de qualidade deixa rastros e afeta os sentidos que o fanatismo tem atualmente. Esse funcionamento de uma memória do dizer, assim entendemos, é sintomático do que aqui denominamos de discurso político autoritário de invocação messiânica que, por sua vez, se mostra como um indício alarmante da relação entre autoritarismo e religiosidade no governo brasileiro.

Por conseguinte, não podemos calar o fato de que essa relação (autoritarismo e religiosidade) produz efeitos materiais que se inscrevem na vida cotidiana, nas políticas públicas, com efeito, na história. Além disso, não se pode calar, tampouco, o fato de que esse modo de 
produção de sentidos (o que chamamos de discurso político autoritário de invocação messiânica) constitui um aspecto fundante de uma língua fascista: "não ser contestado para ser mais bem obedecido, eis ideal regime de escuta da língua fascista" (PIOVEZANI; GENTILE, 2020, p. 19). Indursky (2020), a esse respeito, salienta que as palavras por proferidas pelo atual presidente rompem

[...] com o princípio ético da aceitabilidade que o lugar discursivo de presidente pressupõe, deixando explícitas as marcas do que estou designando de língua fascista. Vale dizer: não se trata mais de uma memória atualizada pelo discurso, como ocorria quando era deputado. Agora, no lugar discursivo de presidente, a língua fascista apresenta marcas de sua efetiva presença e atualidade. Dizendo de outro modo: a língua política com que o capitão-presidente exerce o poder é uma língua fascista (INDURSKY, 2020, p. 376).

Não pretendemos, ao trazer Klemperer e Hitler, traçar uma relação direta, termo a termo, com os discursos do atual presidente brasileiro, haja vista que "a história não se repete, mas as comparações entre fenômenos históricos [discursividades] e agentes políticos costumam esclarecer zonas mais ou menos obscuras dos fatos sociais ou concorrem para mais bem compreendê-los" (PIOVEZANI; GENTILE, 2020, p. 45). Não pretendemos, ainda, adentrar à seara da pertinência da utilização do termo "fascista" para caracterizar o trigésimo oitavo governo brasileiro, mas é possível (e necessário), ler os discursos que circulam nas condições de produção atuais como discursos fascistas. Como analistas de discurso, entendemos que a palavra tem potencial destrutivo; a palavra envenena, evocando mais uma vez a metáfora de Klemperer. Logo, mantemos a escuta atenta ao discurso, à língua fascista, porque sabemos que não há discurso sem história, tampouco sem ideologia.

\section{REFERÊNCIAS}

ALTHUSSER, Louis. Aparelhos Ideológicos de Estado: Notas sobre os Aparelhos Ideológicos de Estado (AIE). Rio de Janeiro, Graal, 1985.

AMES, José Luiz. "Religião e política no pensamento de Maquiavel". Kriterion. Faculdade de Filosofia e Ciência Humanas da UFMG, Belo Horizonte, v. 47, n. 113, p. 51-72, jun. 2006. Disponível em: http://www.scielo.br/scielo.php?script=sci_arttext\&pid=S0100512X2006000100003\&lng=en\&nrm=iso. Acesso em: 22 set. 2020. 
CLAVAL, Paul. "Política, espaço e cultura: as ligações entre poder e religião". Confins. OpenEdition, v. 12, jul. 2011. Disponível em: http://confins.revues.org/7115. Acesso em: 20 set. 2020.

COURTINE, Jean-Jacques. Análise do discurso político: o discurso comunista endereçado aos cristãos. Trad. Cristina de Campos Velho Birck et al. São Carlos, EdUFSCar, 2014.

FREITAS, Ronaldo Adriano. Instrumentação linguística em rede: análise discursiva de dicionários online. 2020, 216f. Tese (Doutorado em Estudos de Linguagem). Programa de Pós-Graduação em Estudos de Linguagem, Universidade Federal Fluminense. Niterói, UFF, 2020.

HEINSFELD, Adelar. O Cetro contra o Báculo: a questão religiosa brasileira no Parlamento Imperial. Revista Brasileira de História das Religiões, v. XIV, p. 193-219, 2021.

HITLER, Adolf. Minha luta. [PDF]. 1934.

INDURSKY, Freda. O teatro do grotesco como cenário da desconstrução do Brasil. Revista da ABRALIN, v. XIX, n. 3, p. 365-388, 2020.

KLEMPERER, Victor. LTI: a linguagem do Terceiro Reich. Rio de Janeiro, Contraponto, 2009.

MAQUIAVEL, Nicolau. O Príncipe. São Paulo: WMF/ Martins Fontes, 2011.

ORLANDI, Eni Puccinelli. A linguagem e seu funcionamento: as formas do discurso. 6 ed. Campinas: Pontes, 2011.

PECHEUX, Michel. O estranho espelho da análise de discurso. In:

COURTINE, Jean-Jacques. Análise do discurso político: o discurso comunista endereçado aos cristãos. Trad. Cristina de Campos Velho Birck et al. São Carlos, EdUFSCar, 2014.

PIOVEZANI, Carlos; GENTILE, Emilio. A linguagem fascista. 1 ed. São Paulo: Hedra, 2020 .

UOL. "Sou messias, mas não faço milagres" diz Bolsonaro sobre recorte de mortes. 28. abr. 2020. Disponível em: https://noticias.uol.com.br/videos/2020/04/28/sou-messiasmas-nao-faco-milagres-diz-bolsonaro-sobre-recorde-de-mortes.htm. Acesso em: 22 set. 2020 .

VILLAÇA, Antônio Carlos. História da questão religiosa no Brasil. Rio de Janeiro, Francisco Alves, 1974.

RECEBIDO EM: 26/08/2021

ACEITE EM: 27/09/2021 